Published in Business horizons, 2017, vol. 60, no. 5, pp. 715-723 which should be cited to refer to this work. DOI: 10.1016/j.bushor.2017.05.015

\title{
Internationalization strategies of emerging market banks: Challenges and opportunities
}

\author{
Joseph C. Marques ${ }^{1}$, Anna Lupina-Wegener ${ }^{1}$, Susan Schneider ${ }^{2}$
}

\begin{abstract}
The greatly improved economic fundamentals of the major emerging economies over the last decade have propelled several emerging banks into the ranks of the world's largest. Despite their importance in the global economy, the internationalization of emerging market banks remains an understudied phenomenon. This article examines factors that may influence the internationalization strategies of emerging market banks in the private banking sector, both when going abroad (take-off) and upon arrival in a host country (landing). The private banking sector is of significant interest given its importance in many leading financial centers around the world while undergoing major transformation due to the worldwide financial crisis, several recent scandals, and a fast-changing regulatory environment. We highlight the internationalization strategies of two banks from emerging countries, China and Brazil, and their experience in Switzerland's traditional private banking sector. These two cases highlight factors that may influence successful internationalization such as prior industry experience, existing client base, entry strategy, ownership type, and the liability of foreignness. Our findings offer valuable implications for managers from other emerging economies by providing a better understanding of how emerging market banks expand internationally.
\end{abstract}

\section{Growing wealth in emerging markets}

Global wealth continues to grow and to produce an increasingly large number of high net worth individuals (HNWIs), especially in emerging countries. A dramatic shift in global wealth distribution is currently taking place around the world, mainly in the Asia-Pacific region where the number of HNWIs is growing faster than the rate of GDP in most countries. Many of these individuals are entrepreneurs who demand access to the same investments and services offered to their counterparts in developed countries. Some of this new wealth has found its way to the leading private banking centers around the world. Several well-capitalized and wellmanaged emerging banks are gradually entering a select group of major institutions in international private banking to claim their share of this lucrative sector, encouraged by the fact that more and more of the HNWI universe is composed of citizens and residents from emerging economies. This represents challenges and opportunities for both emerging market banks (EM-banks) and traditional banks.

Banks must be prepared to handle increasingly sophisticated demands from this new emerging entrepreneurial class (including both personal and corporate clients). All major institutions in private banking aspire to provide a global range of products and services and to capture an increasing number of these valuable clients. An attractive option for large emerging banks is to internationalize and gain the necessary private banking knowledge abroad in order to assimilate useful business know-how for the benefit of their offshore and onshore clients (normally the larger share of a bank's wealth management business who benefit from any upgrade in a bank's global brand and reputation).

\footnotetext{
${ }^{1}$ School of Engineering \& Business of the Canton of Vaud, University of Applied Sciences \& Arts of Western Switzerland, Yverdon-les-Bains, Switzerland

${ }^{2}$ University of Geneva, Geneva, Switzerland
} 


\subsection{Increasing international role of emerging market banks}

Greatly improved economic fundamentals of the major emerging economies over the last decade have propelled several banks from emerging countries into the ranks of the world's largest (either by assets and/or capital). Of the top 50 banks in the world in 2015 (in total assets), 22 were from emerging countries (Daniels, 2016). Despite growing wealth, most emerging market banks currently provide relatively limited private banking services to their domestic high net worth clients ${ }^{3}$. Historically, clients from emerging markets have invested abroad for a number of reasons: economic volatility and the lack of political stability in their home country, investment diversification, better service, and tax avoidance. Clients from emerging markets have traditionally placed their investments in developed markets, including the usual wealth management capitals around the world, such as Switzerland, and with leading international private banks. Nevertheless, EM-banks are poised to become increasingly important participants in international private banking. As they grow in size,

\subsection{Emerging market banks and Swiss private banking}

The private banking sector is of significant scholarly and business interest as it is undergoing major transformation due to the worldwide financial crisis, several recent scandals, and a fastchanging regulatory environment. Switzerland has been the historic center of international private banking with many family-owned banks as well as large global banks embedded in the local institutional and social fabric. This provides an interesting base from which to explore internationalization strategies, motives, and methods of banks from emerging countries and to better understand the challenges and opportunities they face upon entry into the Swiss bastion of private banking.

The entry of EM-banks into the Swiss private banking sector also represents a timely research topic given the substantial restructuring and concentration of the sector since the 2008 financial crisis. In addition, this sector has faced major upheavals due to increased transnational regulation, pressures by international authorities regarding tax evasion, and the loss of traditional competitive advantages such as bank secrecy. Private banking is currently characterized by overcapacity, a trend captured in the important layoffs that have recently taken place. Indeed, the total number of banks in Switzerland decreased from 283 to 275 in 2014 while the number of foreign banks decreased from 145 to 129 from January 2012 to May 2013 (Kirchfeld \& Logutenkova, 2013). The 2014 Annual Report of the Association of Foreign Banks in Switzerland listed 118 foreign banks as members at the end of 2014, representing $42 \%$ of all banks in Switzerland. While banks and other financial intermediaries struggle to adapt to the evolution of the sector, additional research is needed to understand the implications of the arrival of emerging banks.

\footnotetext{
${ }^{3}$ We use the terms wealth management and private banking interchangeably to mean the provision of customized banking services and investment advice to high and ultra-high net worth individuals together with an ever-increasing number of HNWIs and a greater share of wealth created by their compatriots, EM-banks will seek to internationalize and capture a share of the growing business of managing both onshore and offshore emerging wealth.
} 
A handful of emerging banks from Brazil, Russia, India, and China (the BRIC countries) have entered the Swiss private banking market. While there are several banks from other emerging economies such as the Persian Gulf and Asian countries, there were, until recently, a total of five banks from BRIC countries in Switzerland: Banco Itau and J. Safra Sarasin from Brazil, Hinduja Bank from India, and Sberbank and Gazprombank from Russia. Another Brazilian bank, BTG Pactual, acquired Lugano-based BSI (Banca della Suizzera Italiana) the 11th biggest Swiss private bank with approximately $\$ 90$ billion in assets under management (and formerly owned by Italian insurer Generali) in September 2015 but quickly sold it in early 2016 under pressure to sell assets to shore up its capital following events linked to the Petrobras scandal in Brazil. Meanwhile, China Construction Bank (China's second largest stateowned bank) opened its branch in Zurich in January 2016.

Given the economic growth of emerging countries and the rising presence of EM-banks around the world, it is important to understand the factors that may influence their internationalization strategies both when going abroad (take-off) and upon arrival in the host country (landing). In this article, we address the following questions:

- What are the internationalization strategies, motives, and methods of EM-banks when entering the private banking sector in Switzerland?

- Which factors may influence EM-bank internationalization strategies?

- What are the challenges and opportunities that EM-banks face upon entry into Switzerland?

Drawing on the literature on the internationalization of emerging market companies (Jormanainen \& Koveshnikov, 2012; Luo \& Tung, 2007), we focus on a specific industry (private banking) and on specific setting (Switzerland) in order to provide greater understanding of the forces driving the internationalization strategies of EM-banks as well as the challenges and opportunities faced by these banks upon arrival. In addition, we focus on private banking given its strategic importance to the Swiss economy. Based on a detailed analysis of secondary data sources, complemented by off-the-record discussions with bankers, we provide examples of two banks representing two very different experiences, detailed in the following sections. Ourcase studies reveal factors which may have impacted the strategies of each bank and contribute to a better understanding of the internationalization strategies of EM-banks.

\section{Chinese and Brazilian banks in Switzerland}

Internationalization strategies of developed banks have attracted a fair degree of research interest, but internationalization strategies of emerging banks remain largely underinvestigated (Aulakh, Kotabe, \& Teegen, 2000; Zeng, Shen, Tam, \& Wan, 2010). While banks from developed countries may face constraints to sustainable internationalization due to low levels of capital despite a positive market image, banks from emerging economies may, alternatively, suffer from a relatively negative image in international markets despite high levels of capital (Petrou, 2009). Venturing into highgrowth markets may also be driven by irrational motives such as opportunism and imitation as witnessed in the internationalization strategies of banks from developed countries (Grant \& Venzin, 2009). In order to explore beyond the existing theories of emerging market multinational corporations (MNCs), we look at internationalization strategies in knowledge-intensive services (e.g., private banking) by emerging market companies (banks) by adopting a phenomenon-based approach (Von Krogh, Rossi-Lamastra, \& Haefliger, 2012). As with any study of new phenomenon, the use of case studies helps uncover several relevant factors influencing internationalization strategies of EMbanks. In this article, we compare the different experiences of two EM-banks, Bank of China 
(BoC) and J. Safra Bank (later called J. Safra Sarasin), upon entering the private banking sector in Switzerland. This comparison highlights different approaches to internationalization and identifies relevant factors, as well as challenges and opportunities faced by the two banks.

\subsection{Bank of China}

Bank of China had a 4-year experience in Switzerland, from 2008 to 2012. BoC is one of the world's biggest banks as well as the oldest bank in China (established in 1912). It is one of China's big five state-owned commercial banks together with Industrial \& Commercial Bank of China, China Construction Bank, Agricultural Bank of China, and Bank of Communications. BoC is also the only emerging bank considered to be "systemically important" in the list of the world's largest 29 banks (Rabinovitch, 2011).

BoC has been present in London since the 1920s. Given its international experience in retail and corporate banking, the bank's London arm was selected to develop and manage the private banking operation based in Switzerland - BoC (Suisse). Though basic private banking services have been offered in China since 2007, this niche activity is still relatively underdeveloped in China. The initial plan was to provide services for first-generation mainland entrepreneurs who were key clients of the commercial bank as well as to cater to Western clients interested in investing in China. Following its establishment in 2008, the bank's objectives included: (1) entry into the high-profile Swiss private banking business; (2) management of external funds invested directly in China; and (3) distribution of products dominated by renminbi (PRC currency) in Switzerland.

Rather than purchasing a bank directly, BoC's strategy in Switzerland began with the purchase of $70 \%$ of an existing asset management company (Heritage Fund Management - HFM) from a small family-owned private bank in Geneva (Banque Heritage). Through the asset management company, $\mathrm{BoC}$ was later able to obtain a banking license to engage in private banking activity under the name of Bank of China (Suisse). The former manager of HFM became the CEO of BoC (Suisse) while personally retaining partial ownership (approximately $30 \%$ ) of the original asset management company, which provided investment products to the bank. A Lebanese national, the new CEO had experience working in Switzerland and was responsible for hiring the local management team (Baumann, 2011).The bank's board of directors included several highly regarded and experienced local Swiss private banking specialists. The general management of BoC in London and in Beijing, however, had little prior experience in private banking, which greatly limited their understanding of the bank's operating process and business strategy (China Daily, 2008). Furthermore, even relatively minor decisions had to pass through London and often were followed by numerous calls to and from Beijing (Baumann, 2011). Eventually, BoC (Suisse)'s top local managers left and the bank's head office in Beijing assumed responsibility for the Swiss operation (Bilan, 2011). Soon afterwards, BoC reduced the number of funds available from its subsidiary, BoC (Suisse) Fund Management Co., resulting in financial losses and several lawsuits from investors. BoC (UK) was ultimately forced to increase its capital by GBP 110 million (British pounds) to cover the losses of its Geneva subsidiary, estimated to be in theorder of CHF 50 million (Swiss francs). 
BoC attempted to convince the local Swiss regulator, FINMA, to change its banking license and allow BoC (Suisse) to conduct additional types of banking services (i.e., trade finance). The bank's request ultimately was denied. In July 2012 it was announced that BoC (Suisse) would be taken over by a well-known Swiss bank, Julius Baer, in the form of a strategic partnership. At the time of the takeover, it was estimated that BoC (Suisse) managed less than $\$ 1$ billion in assets (Davies \& Shotter, 2012). Shortly thereafter, BoC announced it would concentrate its private banking efforts in Asia and launch a new private banking service in Hong Kong and in Macau to deal with Chinese HNWIs.

\subsection{J. Safra Bank}

J. Safra Bank's origins in Switzerland date back to 2000 with the purchase of Uto Bank in Zurich, later renamed in honor of the family's founding patriarch (Moreira, 2014). The group's current owner, Joseph Safra, is a descendant from a line of bankers in Brazil with origins in Aleppo, Syria. The family is well-known in international banking circles since the group's eldest brother, Edmond Safra, had established the Trade and Development Bank and the Republic National Bank that was later sold to HSBC in 1999 (Jobin, 2012). The Safra banking group in Brazil is dedicated to small and medium-sized companies as well as private clients and is one of the country's largest privately-held banks.

J. Safra Bank has close ties with its clients in Brazil and around the world. It is known for the hands-on management style of its owners, who are experienced private bankers, and as a specialist institution regarding investments in Brazil. The bank's strategy is based largely on its belief that clients from emerging countries, including Brazil, are growing at a fast rate and have an increasing appetite for the services and products of Swissbased banks (Pavoni, 2014a).

J. Safra Bank is run currently by the family's third generation, together with professional managers. While the bank is profitable due to a significant base of existing offshore assets held by Brazilian clients, its ultimate challenge remains to develop a significant number of clients from developed countries with the respective upgrading in its overall reputation as a leading name in international private banking. J. Safra Bank (Suisse) gained a significant boost to its business from the large number of Brazilian clients with accounts in Switzerland held mainly at Republic National Bank, founded by Edmond Safra and which gradually moved to J. Safra Bank after Republic National Bank was purchased by HSBC Switzerland (Benoit-Godet, 2013).

In 2011, J. Safra Bank (Suisse) purchased a majority position in one of Switzerland's oldest private banks, Bank Sarasin (Simonian, 2011). The traditional family-owned Swiss bank was purchased from Dutch bank Rabobank (which had previously bought Sarasin in 2002) for over $\$ 1$ billion in cash. The new entity, J. Safra Sarasin, continued its expansion by seizing the opportunity to purchase the Swiss private banking business of American-owned Morgan Stanley Bank (Suisse) in 2014, giving J. Safra Sarasin greater recognition in the local Swiss marketplace as well as enhanced visibility and a wider international client base. J. Safra Sarasin is currently Switzerland's seventh largest banking group in Switzerland in terms of tier 1 capital (J. Safra Sarasin, 2015).

\section{Internationalization strategies of Bank of China and J. Safra}

The chosen case studies highlight different approaches to entering the private banking sector in Switzerland. 


\subsection{Bank of China's failed strategy}

BoC's move to Switzerland seems rather opportunistic and encouraged by China's 'go global' policy for its state-owned banks. The bank's value proposition regarding the Swiss private banking market remained unclear throughout its 4 -year experience. BoC found neither a sizeable number of local Chinese clients nor a suitable partner institution to guarantee its successful entry into the Swiss private banking market. The $\mathrm{BoC}$ case highlights the importance of the existence of an initial local base of Chinese clients as well as the overall size of the potential client pool (critical minimum) in Geneva in order to guarantee sufficient revenue to cover heavy initial startup and technology costs. BoC's experience may also reflect the profile of today's HNWIs from China - first generation mainland entrepreneurs who have made a fortune in a short period of time and who are primarily interested in a quick return on investments and competitive performance as opposed to the traditional longterm and relationship-driven profile of most private banking clients. Furthermore, given that BoC is government-owned, Chinese expatriates and other HNWls may have preferred to place their money in a Swiss bank with an established reputation to avoid any unnecessary government scrutiny.

The case of $\mathrm{BoC}$ also demonstrates certain cultural and institutional barriers to entry. BoC had a difficult relationship with the Swiss regulator, FINMA, which denied its request to broaden its original banking license. Informal conversations with local market commentators suggest that BoC's Chinese management was offended by having to deal with junior officials at FINMA. The tight control by Beijing over decisions and the lack of autonomy of the Swiss-based bankers reflects the importance of hierarchy and centralized decision making in China that was not received well by the Swiss-based management. BoC also faced the challenge of overcoming its liability of foreignness as well as its liability of outsidership, since it was penalized for its apparent lack of knowledge of the business and local environment (De SáPinto, 2008) as well as an unclear business plan. In addition, and despite the abundance of capital, the global image of China posed an additional challenge for the bank: overcoming its liability of country of origin (Petrou, 2009).

The case of $\mathrm{BoC}$ also reflects problems associated with the early stages of the internationalization process in the form of an incremental 'learning by doing' approach. Research has shown that, in Chinese companies, decisions are often made as 'guestimates,' preferring to take ad hoc decisions to making plans (Inbar, 2010) and creating a repertoire of flexible response options and risk hedging strategies (Huang, 2009). The eventual choice of culturally similar environments (Hong Kong and Macau) as future entry points into the private banking business is in line with early internationalization strategies of MNCs as initial crossborder forays are often determined by geographic, linguistic, or cultural proximity or by personal networks (Schneider, Barsoux, \& Stahl, 2014).

\subsection{J. Safra Bank's successful strategy}

In contrast, Brazilian bank J. Safra had more experience in private banking and a longer presence in Switzerland, and was able to successfully leverage its country-specific advantages as well as its firmspecific advantages (Rugman, Verbeke, \& Nguyen, 2011). Brazil has a sophisticated domestic banking system and a more developed private banking sector (the largest in Latin America). Banco Safra's firm-specific advantage is the result of its greater experience, highly qualified staff and management, and its visibility as a leading private banking institution. It may also benefit from its first mover advantage regarding other Brazilian banks in Switzerland (i.e., Banco Itau) and the availability of an existing pool of Brazilian and other emerging market clients (including former clients from HSBC/ Republic National, as well as from the bank's own client referral pipeline in Brazil). It did not suffer from a liability of outsidership 
as much as BoC. J. Safra's acquisition of Swiss bank Sarasin enhanced its Swiss image given Sarasin's reputation concerning ethical investments and corporate social responsibility. This greatly reduced its liability of foreignness as well as any liability of country of origin. Furthermore, its family business culture, which is largely relationship-based, fits well with the private banking culture in Switzerland and its tradition of family-owned private banks. Thus, J. Safra is an example of an emerging bank group that successfully managed the opportunity to leverage its emerging market background, know-how, and experience into an enviable position as an established private banking player in Switzerland.

\section{Factors in internationalization strategies in private banking}

These two case studies highlight factors that help explain different experiences upon entering the Swiss private banking sector as illustrated in the table below (Table 1).

\subsection{Experience in private banking}

Based on the analysis of the two cases, it is clear that prior private banking experience is an important factor when it comes to entry into the private banking sector and successful access to clients from both emerging and developed countries. Despite the fact that both banks had broad international banking experience prior to their arrival in Switzerland, J. Safra Bank had considerably more private banking experience compared to BoC. BoC's experience was focused mainly on international commercial banking and the delivery of a basic level of private banking services and products to Chinese individuals and corporate clients. J. Safra Bank had a longer presence in Switzerland, considerable prior success in serving both Brazilian and nonBrazilian clients, and greater experience with the acquisition of several Swiss private banks.

\subsection{Existing base of clients from home country}

J. Safra was able to draw from an existing pool of Brazilian HNWIs who were familiar with private banking services and products. Based on its experience and reputation in Switzerland, many Brazilian and other clients from emerging countries placed their trust in J. Safra Bank. In contrast, potential clients approached BoC (Suisse) with some hesitation due to the bank's lack of reputation in private banking and China's limited tradition of corporate governance. Furthermore, Chinese HNWIs may have preferred to place their money with Swiss banks given their positive image and reputation as well as to avoid scrutiny since China's central government owns most Chinese banks.

\begin{tabular}{|l|l|l|}
\hline & J. Safra Bank & BoC \\
\hline $\begin{array}{l}\text { Prior managerial experience in international private } \\
\text { banking }\end{array}$ & Yes & No \\
\hline Existing base of clients from home country & Yes & No \\
\hline Entry strategy & M\&A & Hybrid \\
\hline Type of ownership & Family & Government \\
\hline Liability of foreignness/Liability of outsidership & No & Yes \\
\hline
\end{tabular}

Table 1. Major factors in internationalization in private banking

\subsection{Entry strategy}

J. Safra entered the Swiss market after several years of experience with domestic private banking in its home market in Brazil. It acquired an existing Swiss bank, Uto Bank, based in Zurich, in 2000 followed by Bank Sarasin in 2011. Furthermore, it benefited from the controlling family's international experience (Edmond Safra's Republic National Bank). Its internationalization strategy was based on these competitive advantages that were clearly in line with its strategic goals. BoC, despite its long international experience, had little private 
banking experience at home or abroad. BoC opted for a hybrid model whereby it entered the Swiss market by investing in an asset-management company (which, unlike banks, did not offer a broad range of private banking services) and only subsequently obtained a private banking license. In addition, J. Safra was managed directly by family members and professionals, while BOC hired Swiss bankers who eventually left due to limited autonomy.

\subsection{Type of ownership: Government versus family}

The Chinese government has played a key role in most internationalization attempts of large stateowned Chinese banks, including BoC, given its 'go global' policies and ample availability of resources. Yet, despite plenty of capital, BoC suffered from China's global image - liability of country of origin (Petrou, 2009) - and concerns about corporate governance and the role of the Chinese government.

In contrast, the family-ownership model chosen by J. Safra matched the traditional Swiss private banking culture based largely on long-term relationships and trust built over time. As a privately-held bank, it was also free from many of theshort-term pressures of its larger publiclyheld competitors as well as from government interference (Parente, Cyrino, Spohr, \& Carvalho de Vasconcelos, 2013). Previous research on Brazilian MNCs has identified a preference for Brazilian firms to go abroad with little official government support and by using their own resources (Fleury \& Fleury, 2014; Parente et al., 2013).

\subsection{Liability of foreignness and liability of outsidership}

These two cases present different experiences regarding the level of knowledge of local banking regulations and access to qualified local talent. Swiss authorities insist on a fit and proper profile for executive management and board members in Swiss financial institutions and require that senior managers possess a degree of 'Swissness' (if not Swiss passports), such as knowledge of Swiss procedures, traditions, and know-how. J. Safra, in Switzerland since 2000, has had a longer learning curve regarding Swiss private banking culture, which allowed it to develop a deeper understanding of the local market, a larger client base, and a wider network of contacts compared to BoC. Given its greater name recognition and longer presence in Switzerland, J. Safra was gradually viewed as a Swiss bank or at least one imbued with a greater degree of Swissness. BoC was largely perceived as a Chinese bank and considered a less successful and trustworthy brand (Pavoni, 2014b). BoC retained a strong Chinese identity and a negative home country image, which was strongly played up in the Swiss media during its subsequent financial problems. In contrast, related research (Lupina-Wegener, 2013) has shown that newly-arrived western banks in Poland maintained local well-established Polish banking brands in order to establish and sustain trust with Polish clients.

\section{EM-banks and the future of private banking}

Emerging banks are beginning to seize the opportunity to provide private banking services to a growing number of HNWIs, including more and more clients from their own countries. The propensity of wealthy individuals to entrust external parties with the management of their money is partly dependent on factors such as culture, trust, and financial literacy and consequently varies from region to region. Emerging banks have specific advantages in their understanding of their clients' culture and by becoming increasingly competitive and better equipped to service these clients in several of the main private banking centers around the world. 
Many developed countries have negotiated double taxation agreements and tax information exchange agreements with the major private banking centers around the world, including Switzerland. This has led to greater regulatory convergence between most offshore and onshore markets. Banks are being forced to review their traditional value propositions and find alternative ways to differentiate themselves. While size and experience in the sector are fundamental, the growing number of new clients from emerging economies is fostering change in the type of services offered, pricing structure, and marketing strategies of all banks.

This comparative study highlights challenges (BoC) as well as opportunities (J. Safra) that EMbanks face on entering the Swiss private banking sector. The following suggestions serve as prescriptive recommendations for future EM-bank development in the private banking sector.

\subsection{Reduce the knowledge gap}

A newly affluent class of emerging HNWls demands increasingly greater product and service diversification as many potential banking clients have global interests and seek more international investment options. All major banks aspire to provide a global range of products and services to capture an increasing number of these valuable clients. By going international, large emerging banks can obtain the necessary private banking knowledge abroad and assimilate useful know-how for the benefit of their offshore and onshore clients. A quick and effective learning process can greatly reduce the overall knowledge and know-how gap between traditional and emerging banks.

Emerging banks should leverage their relative competitive advantages of being culturally closer to such clients and possessing relevant expertise regarding emerging market investments (afavorite investment option of emerging clients). In addition, EM-banks often have a stronger capital base than many developed banks.

\subsection{Keep up with the regulatory environment}

As emerging economies grow, emerging banks must aim to provide high-value products and a broad range of investments and customized services to their emerging clients in order to compete better with their competitors. This often entails changes and adjustments in legislation and regulatory controls in the bank's home country in line with international standards. The financial crisis has led to frequent regulatory changes and constant demands for additional investments in technology and compliance matters, placing enormous strains on banks around the world as well as radically altering the private banking business environment. The increased costs and responsibilities impact both developed and emerging banks.

\subsection{Reasons to internationalize}

The accelerating shift in economic power from the developed economies to the emerging world is dramatically changing the wealth management industry as banking and financial power shifts from the G7 developed countries to the BRICS and next11 emerging countries. The establishment of a new bank or the acquisition of an existing bank in a traditional financial center by an emerging bank is motivated by many factors including: (1) to boost assets under management (AuM) in order to reach critical mass; (2) to diversify current clients' asset mix; (3) to access new products; (4) to gain additional market knowledge, greater visibility and presence; and (5) to enhance brand recognition. 
Many EM-banks have traditionally benefited from large, profitable, and often protected domestic markets. However, to obtain the necessary knowledge and reputation and become a recognized name in international private banking they must internationalize further and enter traditional private banking centers of excellence.

\subsection{Going forward: Look to Switzerland}

Private banking traditionally was viewed as an attractive niche for many banks with low capital requirements, substantial liquidity, and attractive margins. Much has changed since the beginning of the financial crisis and all banks currently face increased business complexity and growing pressure due to the effects of the economic crisis and the rising cost of regulation, including the adoption of a full tax compliance model. Competing in this niche has become more costly and has changed the business matrix for all participants.

The banking industry is expected to experience additional consolidation that, while reducing the number of existing players, will allow for the emergence of new players from emerging countries. While developed banks are forced to rethink (and possibly reduce) their international corporate footprint (offshore vs. onshore presence), new emerging banks must expand abroad in order to connect more effectively with large diasporas of fellow emerging HNWIs and follow their corporate 'national champions.' With increased internationalization, they can obtain additional know-how and enhance their brand, often for the benefit of their growing domestic wealth management business. To further improve their brand image, emerging banks should continue to seek a degree of 'Swissness' by forging a physical presence in Switzerland. Notwithstanding the gradual erosion of bank secrecy, Switzerland continues to attract a significant amount of the world's wealth due to its reputation for safety, stability, quality service, sophisticated financial markets, and discretion - all the hallmarks of traditional and successful private banking.

\section{Final thoughts}

Global wealth will continue to grow and to produce an increasingly large number of HNWIs globally, especially in emerging countries. Much of this wealth will continue to find its way to the leading private banking centers around the world. Several strong, well-capitalized, and wellmanaged emerging banks will break into the select group of major players in international private banking and take the opportunity to increase their share of this lucrative market, encouraged by the fact that more and more of the HNWI universe is composed of citizens and residents from emerging economies.

Emerging banks should strive to adapt different internationalization strategies driven largely by their desire to gain knowledge and specific private banking know-how for their offshore as well as onshore business. The entry of emerging banks into the exclusive group of leading private banks, though a recent phenomenon, will undoubtedly change the traditional private banking sector as we know it. This phenomenon will yield new institutions (from consolidation and M\&A activity) as well as impact the marketing, training, and management functions of many existing institutions.

The current list of the world's leading banks includes a growing number of banks from emerging countries. Many of these banks have been slow to internationalize, often due to the size and attractiveness of profitable domestic markets. A few, however, have initiated their process of internationalization by expanding initially into neighboring countries and following some of their 'national champions' and other large corporations abroad as well as HNWIs from their home country. 
Emerging banks will enter the private banking market by leveraging their competitive advantages including their deeper knowledge of the investment behavior and service preferences of emerging clients. Faster growing economies from emerging countries will produce bigger banks wishing to carve a niche in the profitable private banking business, attract a growing number of emerging clients, and pose additional challenges to the traditional private banking sector. Several of these emerging banks have developed very competitive world-class technology and retail banking networks at home while offering limited private banking services to their affluent domestic clients. These emerging banks will soon meet, if not exceed, industry performance benchmarks and will increasingly turn their attention to international private banking and further contribute to the industry's rapidly changing environment and future prospects.

\section{References}

Aulakh, P.S., Kotabe, M., \& Teegen, H. (2000). Export strategies and performance of firms from emerging economies: Evi- dence from Brazil, Chile, and Mexico. Academy of Manage- ment Journa1, 43(3), 342-361.

Baumann, C. (2011, April). A Genève, le diktat de Pékin. Geneva: Swiss Bank.

Benoit-Godet, S. (2013, June 25). Jacob Safra mise sur la place financière Suisse. Bilan. Available at http://www.bilan.ch/ argent-finances-les-plus-de-la-redaction/ jacob-safra-mise-sur-la-place-financiere-suisse Bilan. (2011, July 4). Bank of China attaquée par la direction des

fonds 788. Available at http://www.bilan.ch/argent- finances-exclusif/bank-china-attaquee-parla-direction- des-fonds-788

China Daily. (2008, November 29). Bank of China opens subsidiaries in Switzerland. Available at http://www.chinadaily.com. cn/business/2008-11/29/content 7253540.htm

Daniels, V. (2016). The largest 100 banks in the world. HITC. Available at http://www.hitc.com/en-gb/2016/04/ 13/sp-global-market-intelligence-ranks-the-largest-100banks-in-the/

Davies, P. J., \& Shotter, J. (2012, July 23). Bank of China abandons Swiss dream. Financial Times. Available at https://www.ft.com/content/3d1e5394-d4dc-11e1-b476- 00144feabdc0

De SáPinto, M. (2008, November 28). Bank of China gets go-ahead for Swiss private bank. Reuters. Available at http://uk. reuters.com/article/bankofchina-swiss-idUKLNE4AR01M 20081128

Fleury, M. T., \& Fleury, A. (2014). Country of origin effects on internationalization: Insights from Brazil. In A. Cuervo- Cazurra, \& R. Ramamurti (Eds.), Understanding multi- nationals from emerging markets (Vol. 1, pp. 242-267). Cambridge, UK: Cambridge University Press.

Grant, R. M., \& Venzin, M. (2009). Strategic and organisational challenges of internationalisation in financial services. Long Range Planning, 42(5), 561-587.

Huang, K.-F. (2009). How do strategic groups handle cognitive complexity to sustain competitive advantage? A commentary essay. Journal of Business Research, 62(12), 12961298.

Inbar, Z. (2010). The influence of national culture and institutional environment on strategic thinking: The case of Israeli companies operating in China (Unpublished doctoral dissertation). University of Melbourne, Melbourne, Australia.

J. Safra Sarasin. (2015). Annual report. Available at https:// www.jsafrasarasin.com/internet/com/jssh annual report 2015.pdf

Jobin, M.-H. (2012, July 31). Gestion de fortune: Safra reprend Sarasin et fait coup double.

Tribune de Genève. Available at http://www.tdg.ch/economie/safra-reprend-sarasin-coupdouble/story/13456692

Jormanainen, I., \& Koveshnikov, P. C. A. (2012). International activities of emerging market 
firms. Management Interna- tional Review, 52(5), 691-725.

Kirchfeld, A., \& Logutenkova, E. (2013, June 30). Private banks leave Switzerland as end of secrecy hurts. Bloomberg News. Available at https://www.bloomberg.com/news/ articles/2013-06-30/private-banks-leave-switzerland-as- end-of-secrecy-hurts-profits

Luo, Y., \& Tung, R. L. (2007). International expansion of emerging market enterprises: A springboard perspective. Journal of International Business Studies, 38(4), 481—498.

Lupina-Wegener, A. A. (2013). Human resource integration in subsidiary mergers and acquisitions: Evidence from Poland. Journal of Organizational Change Management, 26(2), $286-304$.

Moreira, A. (2014, May 19). Banco suiço de Joseph Safra quer acelerar crescimento. Valor Economico. Available at http:// www.valor.com.br/impresso

Parente, R. C., Cyrino, A. B., Spohr, N., \& Carvalho de Vasconcelos, F. (2013). Lessons learned from Brazilian multina- tionals' internationalization strategies. Business Horizons, 56(4), 453-463.

Pavoni, S. (2014a). Brazil extends its private banking reach. The Banker. Available at http://www.thebanker.com/Banking/ Private-Banking/Brazil-extends-its-private-bankingreach? ct=true

Pavoni, S. (2014b). Is private banking a global or local game? The Banker. Available at http://www.thebanker.com/Banking- Regulation-Risk/Private-Banking/

Is-private-banking-a-global-or-local-game

Petrou, A. P. (2009). Foreign market entry strategies in retail banking: Choosing an entry mode in a landscape of constraints. Long Range Planning, 42(5), 614-632.

Rabinovitch, S. (2011, November 11). Bank of China talks up its Sifi status. Financial Times. Available at https://www.ft. com/content/37745e94-0c3b-11e1-8ac6-00144feabdc0

Rugman, A. M., Verbeke, A., \& Nguyen, Q.T.-K. (2011). Fifty years of international business theory and beyond. Manage- ment International Review, 51(6), 755-786.

Schneider, S., Barsoux, J.-L., \& Stahl, G. (2014). Managing across cultures (3rd ed.). Essex, UK: Pearson.

Simonian, H. (2011, November 25). Safra Group wins race to buy Bank Sarasin. Financial Times. Available at https://next.ft. com/content/c5331290-179c-11e1-b00e-00144feabdc0 Von Krogh, G., Rossi-Lamastra, C., \& Haefliger, S. (2012). Phenomenon-based research in management and organisa- tion science: When is it rigorous and does it matter? Long Range Planning, 45(4), 277-298.

Zeng, S.-X., Shen, Q., Tam, C. M., \& Wan, T.W. (2010). Interna- tionalization paths of Chinese firms: Evidences from an emerging economy. Journal of Business Economics and Management, 11(2), 297-315. 